Terbit online pada laman web jurnal : http://e-journal.sastra-unes.com/index.php/JILP

\begin{tabular}{|c|c|c|}
\hline \multirow[b]{2}{*}{$\begin{array}{c}\text { Fakultas Sastra } \\
\text { Universitas Ekasakti }\end{array}$} & \multicolumn{2}{|c|}{$\begin{array}{c}\text { (JURNAL, ILMIAH LANGUE AND PAROLE) } \\
\text { VOLUME } 2 \text { NOMOR } 2\end{array}$} \\
\hline & $\begin{array}{c}\text { ISSN : 2581-0804 } \\
\text { (Media Cetak) }\end{array}$ & $\begin{array}{c}\text { E-ISSN : 2581-1819 } \\
\text { (Media Online) }\end{array}$ \\
\hline
\end{tabular}

\title{
THE DEPRESSED FEMALE CHARACTERS FROM THEIR INTIMIDATED SURROUNDING AS SEEN IN THE YELLOW WALLPAPER BY CHARLOTTE PERKIN GILMAN'S, A ROSE FOR EMILY BY WILLIAM FAULKNER'S, AND THE STORY OF AN HOUR BY KATE CHOPIN
}

\author{
Cut Ruby Miranda, Helmita \\ Fakultas Sastra Universitas Ekasakti \\ cutrubymiranda3@gmail.com \\ *Corresponding Author: Helmita \\ Fakultas Sastra Universitas Ekasakti
}

\begin{abstract}
In writing this thesis, the writer discusses the depression of women because of patriarchal traditions, even though they already know about women's rights and freedoms. This patriarchal tradition is that men hold full power over anything and women must always obey the rules of men. The women are required not to do any activities, in terms of education and employment. Women are only allowed to do homework. This applies to all women, both single and married. This began in the 90s, especially in the United States.

In writing the thesis, the writer uses psychological and feminist theories according to Sigmund Freud and Maggie Humm, who will explore the psychological side of women who are oppressed by the existence of this patriarchal custom. The purposes of this paper are: (1) To describe psychological-feminist cases in female characters (2) To analyze psychological-feminists in depressed female characters (3) To explain the psychological-feminist influence with female characters in the short story of The Yellow Wallpaper from Charlotte Perkins Gilman, A Rose For Emily from William Faulkner, The Story Of An Hour by Kate Chopin. The author uses descriptive qualitative methods in processing data. Through analysis of several existing sources and data.

Based on available data, the writer discover how the psychology of depressed female characters from their environment is intimidated based on the short story. In fact women can become depressed because their freedom of expression is hampered and prohibited by tradition. With the writing of this thesis, it is hoped that the public can find out what exactly the meaning of women's emancipation is without having to put down women or men.
\end{abstract}

Keywords: Patriarchal Tradition, Bridled, Depressed Woman Characters

(C) 2019Jurnal JILP

Jurnal JILP (Jurnal Ilmiah Langue and Parole) Vol. 2 No. 2 (2019) ISSN : 2581-0804

This work is licensed under a Creative Commons Attribution-NonCommercial 4.0 International License. 


\section{INTRODUCTION}

The background of the problems provides the reasons for the problem in this analysis. Therefore, the writer begins with describing the depressed female character in short story The Yellow Wallpaper by Charlotte Perkins Gilman, A Rose For Emily by William Faulkner, The Story Of An Hour by Kate Chopin. Before the writer continues the analysis, the writter wants to explain what the depressed character it is.

Depression is a state of low mood and aversion to activity that can affect a person's thoughts, behavior, feelings, and sense of wellbeing. Depressed mood is also a symptom of some mood disorders such as major depressive disorder. People with a depressed mood may be notably sad, anxious, or empty, they may include senses of guilt, irritability, or anger.

Depression according to the psychologist is the grim condition of the day of loneliness, pain, and the opaque feeling that is pathological. Depression caused by intense pain, psychic trauma, guilt, and inferiority. (Kartono: 2002). Kusmanto said depression is a symptom and a sad, psychopathological sad syndrome that is accompanied by loss of interest, increased fatigue, and decreased energy.

The writer chooses this problem because very many women who were oppressed and depressed were caused by people closest to them. Most women cannot express their passion. Women are more dominant to stay at home and do homework and so on. Even though women have the same rights as a man.

Here the problem is that women are forbidden to express their passion because of the people around them who hold them back, such as family, friends, and partners. They are more likely to order women to stay at home because if there are women who work outside the home and the surrounding community will label this woman badly and will be ostracized. This will eventually make women depressed and the bad side of depression is attached to women.

"I am glad my case is not serious! But these nervous troubles are dreadfully depressing. John does not know how much I really suffer. He knows there is no reason to suffer, and that satisfies him." Charlotte Perkins Gilman, $\underline{\text { The }}$ Yellow Wallpaper.
Actually, the problem here is that women only need to be given a little freedom of expression and display their talents. Women need to show people around them that they are capable. Women do not want to be identified with the spoiled nature, because in fact, the woman is strong and independent.

"Spring days, and summer days, and all sorts of days that would be her own. She breathed a quick prayer that life might be long. It was only yesterday she had thought with a shudder that life might be long." Kate Chopin, The Story of an Hour.

According to Maramis (1998) defines Depression is a type of state of feeling or emotion with psychological components such as sadness, uselessness, failure, loss, despair, and pathological regret. Depression is also accompanied by somatic components such as anorexia, constipation, blood pressure and decreased pulse. Under such conditions, depression can cause the individual to no longer function naturally in his life.

The writer chooses the depressed female character because she wants ask women to be a stronger woman and she wants to encourage a woman not to become weak. Women should not be regarded as one woman by society or family. Women are creatures that are multitalented and should be ranked top. Women who are privately depressed usually experience psychological disorders that result in this women is depressed. There many cause of depressed women, one of which is a society that excludes or couples who always blame.

Therefore, from the background, the writer chooses "The Depressed Female Characters From Their Intimidated Surrounding As Seen In Charlotte Perkin Gilman's The Yellow Wallpaper , William Faulkner's A Rose For Emily, Kate Chopin The Story Of An Hour" as researcher topic of analysis.In this case, depression from a woman is usually caused by the environment around them such as a partner, close friends, and the surrounding community. If this depression continues, it can make someone crazy and forget their identity. In fact, women are able to do something they want but with the existence of the surrounding environment that prohibits the woman is finally oppressed. 


\section{RESEARCH METHODS}

The data collecting procedures is focused in the process of the writer collect the data. In the collecting data the writer applies library research. It means that the writer applies the data which the writer takes from library. In concern with library research, the writer Charlotte Perkin Gilman's "The Yellow Wallpaper", William Faulkner's "A Rose For Emily", Kate Chopin "The Story Of An Hour" as main data of this research. The writer also collects books as references of this writing and theories to solve the research problems that conveys in this thesis.

\subsection{Method of Analyzing the Data}

In analyzing the data, the information from data collection is processed and presented in form of thesis. In the application, the writer uses structural method. The researcher use structural genetic methods with psychological and feminist analysis. The approach of genetic structuralism is an approach that believes that the literary work is a structure consisting of interrelated categories of categories that form the genetic structuralism of the category is the fact of humanity which means a meaningful structure of all human activities or good behavior of the verbal as well as physical that try to understand by knowing.

\subsection{Technique of Collecting the Data}

The writer uses qualitative analysis research in collecting the data. Sherman and Webb (2005) assume that qualitative research is concerned with meaning as they appear to, or are achieved by persons in lived social situations. Meanwhile, Bogdan and Biklen (1982) state that qualitative research is descriptive which the data is collected in the form of words or pictures rather than numbers.

The research in this research used some steps in collecting the data as follows:

1. Selecting the short story

The research selected the short story carefully, the are many good short story the researcher chooses short story by Charlotte Perkins Gilman's "The Yellow Wallpaper", William
Faulkner's "A Rose For Emily", Kate Chopin "The Story Of An Hour".

2. Read the short story to convince about the story.

The researcher was read the short story by Charlotte Perkins Gilman's "The Yellow Wallpaper", William Faulkner's "A Rose For Emily", Kate Chopin "The Story Of An Hour".

3. Writing the title of the research is the depressed female characters from their intimidated surrounding as seen in Charlotte Perkins Gilman's "The Yellow Wallpaper", William Faulkner's "A Rose For Emily", Kate Chopin "The Story Of An Hour"

The data is taken from the script of three short story by Charlotte Perkin Gilman's "The Yellow Wallpaper", William Faulkner's "A Rose For Emily", Kate Chopin "The Story Of An Hour" with psychological-feminist theory.

\subsection{Technique of Analyzing the Data}

After data collection, the specific steps that writer must take in this research are as follows:

1. Identifying the depressed female characters. The research identified the depressed female character in the short story from analysis by Charlotte Perkin Gilman's "The Yellow Wallpaper" , William Faulkner's "A Rose For Emily", Kate Chopin "The Story Of An Hour".

2. Classifying data from the dialog of the scrip analysis by Charlotte Perkins Gilman's "The Yellow Wallpaper", William Faulkner's "A Rose For Emily", Kate Chopin "The Story Of An Hour" which containing psychological-feminist analysis.

3. Describing the distribution of the use of psychological-feminist analysis in the short story entitled Charlotte Perkins Gilman's "The Yellow Wallpaper" , William Faulkner's "A Rose For Emily", Kate Chopin "The Story Of An Hour".

4. Analyzing and interpreting female character with psychological-feminist by Sigmund Freud and Maggie Humm.

Drawing the conclusion from the data analysis and giving suggestion. 


\section{RESEARCH FINDING}

The writer uses psychology analysis and feminist analysis in this thesis to find the reason for depressed female characters in the short story. Psychoanalysis is a set of theories and therapeutic techniques related to the study of the unconscious mind, which together form a method of treatment for mental health disorders. One of them is the analysis that the writer uses to explore the problems in this short story. This is where literature comes into play. When criticizing in short story can use a psychoanalytic approach can be utilized. Feminist literary criticism is literary criticism informed by feminist theory, or more broadly, by the politics of feminism. It uses the principles and ideology of feminism to critique the language of literature.

The presentation of data findings in this section is related to women who are stressed by the environment such as family, partner, and community. It can be gotten from three short stories. In first short story is written by Charlotte Perkins Gilman, a feminist author. The main character of the story is the female nameless character or the narrator, a wife, and a mother. John, the narrator husband, thinks the narrator is in a temporary nervous depression. Her husband takes her to a kind of treatment or therapy to cure her insanity. So depression is a mental disorder that is temporary and can be cured if done with several therapies. Various kinds of therapeutic causes such as the story above the narrator was depressed the first time she saw a house which she thought was strange and when she entered the house she felt there was something strange about the house. When she entered a room she saw the room was lined with yellow wallpaper

She was increasingly depressed when her husband told her to stay in the room without doing anything, including writing; her husband didn't like if she wrote. Even though writing is one of her hobbies and writing also can reduce her depression but her husband forbade it.

The second short story by William Faulkner's A Rose for Emily. The story presents a topic about an extraordinary woman, Miss Emily, who has a deviation in behavior. Her deviation is related to her psychology and feminist condition. The objectives of this research are to study Miss Emily's psychological problems which can be seen through her actions; the way of thinking and her action to other people. According to the author, what Emily experienced was depression caused by herself, because she didn't want to go out and socialize with anyone. But Emily's father is also a contributing factor why Emily is like this. As we know that since Emily was small, she was always restrained by her father. Her father was too overprotective of her and when her father died Emily felt there were no more people out there who cared about her except her father. This makes Emily closed and doesn't want to know anyone. Actually the case of depression that occurs in Emily can be cured by the frequent Emily socializing with the outside world and adding insight to the outside world so that this can reduce the level of stress

The research on "The Story of An Hour by Kate Chopin" is a great example of a literature book review. The story takes place in the late 1800 s, and at the residence of Louise Mallard. Though the precise location is never revealed, the views of women and the prevalence of railroads suggest that the story occurred in the late nineteenth century. The main character is Louise Mallard, a young woman who "was afflicted with a heart trouble". Brently Mallard is Louise's husband and is believed to have perished in a railroad accident. Mrs. Mallard felt too happy because she had managed to escape the shackles that bound her. But when she wants to enjoy freedom, at that moment the real reality is that her husband is still alive. This made her very surprised and finally died at the same time as she enjoyed her happiness. The results of the study are that Louis Mallard, as the main character is portrayed such as an ordinary and loving stereotyped-kind of wife, independent woman, a stressful woman, as young with a fair, calm face woman, a loving wife, suffered, frail woman, and a modest widow. That two conflicts appeared through the story, the first is Mrs. Mallard against herself and the second is Mrs. Mallard against the environment. The liberal feminism values of Mrs. Mallard in the story can be seen through her feeling after she knew that her husband died. 


\section{CONCLUSION}

Based on the results of the research and discussion described in the previous chapter, the conclusions that can be taken are as follows:

1. Most women in the 19th century were depressed because in the 19th century they adopted a patriarchal tradition that is a social system that places men as the main authority and dominates the role of political leadership, moral authority, social rights and property control. Implicitly this system institutionalized male government and privileges and placed women under men.

2. Women are usually bound by marriage ties and this increasingly makes them not free to express themselves. There are also women who are forced by their fathers to marry men who have high positions and eventually they are shackled by this rule because men consider women to be inferior to them and women cannot do any work other than homework.

3. Most women are isolated in the house. They are prohibited from working, communicating, doing their hobbies, etc. The community considers, if there are women who are still working outside the house it is a social deviation and degrading men as the main power holders.

4. Most women begin to imagine the freedom they will get if they can escape the shackles of this tradition. This causes a woman to do something unexpected like imagining too high to finally kill.

5. This depression is a temporary illness if handled properly. The way to reduce depression in women is to let them express their passion, let women communicate with the outside world, and let them work according to what they like. This can help cure depression experienced by women.

\section{The Students}

The researcher hopes that the students can find a way to improve their ability especially in a short story about a depressed female character.

A further researcher

The further researcher can use the result of this research as a reference to other researchers with different subject. 


\section{Bibliography}

[1]Anderson Amy. 2018. A Rose for Emily by William Faulkner: Summary, Theme \& Analysis.England: Study.com Chapter 12 Lesson 2.

[2]Asmarani, Ratna. 2017. The Stunted Identity of Emily Grierson in A Rose for Emily by William Faulkner. Jawa Tengah: Mason Publishing Vol 1 No 1.

[3]Berg, B. L. 1995. Qualitative Research Methods for the Social Sciences. Boston: Allyn and Bacon.

[4]Bogdan, R.C., at all.1982.Qualitative Reseacrh for Education: an Introduction to Theory and Method.Boston: Allyin and Bocan.Inc.

[5]Chopin, Kate.1894. The Story of anHour.United States: Vogue.

[6]Faulkner, William.1930. A Rose for Emily. United States: National Magazine.

[7]Freud, S. 1896. Further remarks on the neuropsychoses of defence. SE, 3: 157-185. .2010.The ego and the id. SE, 19: 1-66.

[8]Gilman, Charlotte Perkins. 2003. Symbol and Motifs: WordPress.

[9]Grisham John.2014.Charlotte Perkins Gilman Biography. North America: Biography Editorshttps://www.biography.com/people /charlotte-perkins-gilman-9311669 201902-08 9.34 PM.

[10]Hardjana,A. 1991. KritikSastra: Sebuah Pengantar. Jakarta: Gramedia.

[11]Humm, Maggie. 1995. Feminist theory : second edition. USA: Ohio State University Press.

2002.Ensiclopedia of Feminism (terjemahan Mundi

[12]Rahayu).Yogyakarta:FajarPustakaBaru

[13]Kartono, K. 2002. Patologi Sosial Gangguan Jiwa. Jakarta: Raj Grafindo Persada .Kusmanto,at all. 2006. Depresi. Jakarta. EGC.
[14]Lewinsohn,P.M. 2010. Control Your Depression. England: John Wiley \& Sons.

[15]Macleod,Catriona.2017.Feminismandpsychol ogy.sagepublishing.https://us.sagepucom. 2018/12/12 8:09 PM

[16]Maramis, W.F,. 1998. Catatan Ilmu Kedokteran Jiwa. Surabaya: Airlangga University Press

[17]Maslow,A.H. 2010. Motivation and Personality. Newyork: Harper and Row.

[18]Mental Health America. 1995. Depression in Women. England: National Institute of Mental Health http://www.mentalhealthamerica.net/condi tions/depression-women 2018-01-23 8.28 PM.

[19]Pradopo, D.R, at all. 2001. Metodologi Penelitian Sastra. Yogyakarta: PT. Hanindita Graha Widya.

[20]Schimelpfening, Nancy. 2018. Nine Most Common Causes of Depression. Publishing https://www.verywellmind.com/commoncauses-of-depression-1066772 2018-01-23 8.34 PM.

[21]Sherman,R.R, at all. 2005. Qualitative Research in Education: Focus and Methods.Newyork: Taylor \& Francis elibrary.

[22]Sugiyono. 2005. Memahami Penelitian Kulitatif. Bandung: Alfabeta.

[23]Willis Monte. 2018. FAQ on Sudden Death and Myocarditis. New York: MYO Carditis Foundation https://www.myocarditisfoundation.org/res earch-and-grants/faqs/sudden-death-andmyocarditis/ 2019-01-23 8.45 PM.

[24]Xuemei Wan. 2009. Kate Chopin's View on Death and Freedom in The Story of an Hour. China: Jiangsu University Zhenjiang vol 2 no 4. 